\title{
11 Possibilities of supporting exports at regional level
}

One of the effects of globalisation is the growing openness of an economy and its consequences. The progressing liberalisation eliminates traditional tools of protecting manufacturers, including protective tariffs, quota systems, direct support for exports (taking the form of subventions or subsidies) or several quality standards the diversification of which has been hampering international trade.

When the application of these instruments is limited or impossible, there is more competition currently faced by countries, regions and companies, the development of which is to a large extent related to the ability to export.

In this context, the following questions arise:

- How can entrepreneurs be encouraged to take the risk of internationalisation when the economy is open and strongly competitive?

- What are the possible tools (compatible with the EU laws) of supporting exporters at the regional level?

- Do NUTS 2 European regions (for example in Poland and Spain) use these instruments and which of them are most frequently applied?

An attempt to answer these questions is the aim of this paper.

Most topical publications have been used for this analysis: books, articles, publications and documents of the EU. A detailed preliminary survey of the information referring to regional systems of innovation, available at the European Commission website (https://s3platform.jrc.ec.europa.eu/) has been carried out. Provisions referring to the support of exports in the development strategies and regional operational programmes of Polish and Spanish NUTS2 units have also been analysed.

Referring to the first issue, it is good to notice Melitz and Redding (2014), who state that companies operating within the same sector are not homogenous, and only some of them will try to expand to foreign markets. Two fundamental questions emerge in this context:

- if there is a demand from abroad for the products of a given sector, why do some of the companies fail to join "the internationalisation game"?

- the question mentioned in the introduction, i.e. how to encourage the passive ones to start exporting?

The answer to the first question is provided by the results of numerous studies, such as Gawlikowska-Hueckel and Umiński (2016), Brodzicki et al. (2018) and Cieślik (2017).

On the basis of those studies, it can be noted that exporting companies are, as a rule, the larger ones; in Poland, they are mainly export-oriented FOEs which are at the same time importers. Without too much simplification, it may be said that they 
are more familiar with foreign markets (foreign capital involvement), more likely to take the risk (larger own resources) and have a better chance of participation in IIT.

The replies to the questionnaires distributed among non-exporters show their reluctance to start exporting connected with four types of barriers: (i) strictly exportrelated, perceived as external factors such as customs formalities, complicated procedures, the need to respect specific standards, etc., (ii) related to insufficient resources (dearth of capital, finance and human resources), (iii) marketing-related (logistic problems, lack of information, lack of efficient advertising, poor knowledge of foreign market essentials) and (iv) obstacles of a personal nature resulting from attitudes (aversion to taking the risk, insufficient knowledge, reluctance to cooperate) (PWC, 2017).

A survey carried out on a sample of 700 enterprises in Poland (GawlikowskaHueckel and Umiński, 2016) shows that the obstacles most frequently mentioned by non-exporters, discouraging them from going international, are a lot of competition, foreign exchange risk, insufficient information on foreign markets and the absence of good cooperation with other companies.

These entrepreneurs expect national and regional institutions to help them with market research, clarification of procedures, search for business partners or better, more transparent information.

The context of the second question presented in the introduction is more complex. The curbs on the possible use of all export-support tools by the EU member states are connected with respecting the Community laws concerning trade and competition policies (Majkowska-Szulc, 2016).

Trade policy is one of the cornerstones of European integration which has created the framework of 'a level playing field' for the member states in both internal and external trade of the EU and resulted in trade creation and shifting (GawlikowskaHueckel and Zielińska-Głębocka, 2004; Kawecka-Wyrzykowska, 2009; ZielińskaGłębocka, 2012).

This policy is a sole competence of the EU; therefore, the application of exportsupporting tools is strictly limited by the provisions of the European treaties. Regulations concerning trade policy are included under Title II "Common Commercial Policy" of part five "External Action by the Union" of the Treaty on the Functioning of the EU. For the present discussion, the most significant are the provisions that it 
is not possible to infringe on "equal rights for all the entrepreneurs without the EU consent". 26

The EU position concerning the elimination of barriers limiting free trade is strict, which does not mean that the European Commission fails to notice changes taking place in the world trade (Nacewska-Twardowska, 2013). The process of these changes was discussed in the communication from the External Relations Section of the European Commission to the European Parliament, the Council, the European Economic and Social Committee Council, and the Committee of the Regions (European Commission, 2010a). Potential effects of ongoing transformations have also been identified:

- competition is intensifying due to new IT and transport technologies, coupled with the future "green" technologies. They transform not only the way in which added value is generated and distributed, but also contribute to increase in the mobility of goods, services and factors of production, capital in particular (CESE, 2011). This results in the exposure of a greater number of social and economic sectors to foreign competition;

- the role of knowledge and innovation, which have become the engines of growth, has changed. This has had a revolutionary impact on the classical division of labour, consistent with comparative advantages. Countries specialise in "tasks" performed by employees with special skills, thanks to which they gain a competitive edge, also making use of differences in social and tax regulations;

- competition contributes to more innovation, which may result in pay inequalities between unskilled and skilled workers, between people who possess capital and those who do not, between those who work in sectors exporting goods and services, and those who work for internal market-oriented industry;

- this requires synchronisation of activities within the framework of trade policy and other activities, particularly these concerning "transformation and adjustment in the labour market, limiting the emission of greenhouse gases, social and economic cohesion, the single market, as well as cooperation and development”;

- competition for natural, energy and food resources is on the increase, with an impact on terms of delivery; therefore attention must be paid to the security of supplies (European Commission, 2011).

26 Equal rights for all the enterprises related to Treaty provisions which stipulate that within the EU it is impossible (without the EU consent) to: take any action with regard to changes in tariff rates, the conclusion of tariff and trade agreements relating to trade in goods and services, and the commercial aspects of intellectual property, foreign direct investment, the achievement of uniformity in measures of liberalisation, export policy and measures to protect trade such as those to be taken in the event of dumping or subsidies. 
The awareness of these tendencies bore an impact on the preparation by the EC of the new approach to commercial policy. The document stresses that "better economic results are achieved when markets are open to trade" and that the debate and negotiations held within the EU and WTO should focus on the EU trade policy to be of "more strategic and long-term nature" (European Commission, 2011).

The "new approach" also assumes that the efficiency of EC actions will provide a new, deregulated partnership between the Commission, the member states and entrepreneurs operating in third countries, where thanks to the knowledge of the local conditions it is easier to identify barriers to trade and overcome them". The scope and scale of the Commission's activities should be adequate to the importance of various markets.

The other policy limiting the possibility of direct support for enterprises is the competition policy. This policy is regulated by the Treaty on the Functioning of the European Union (Art. 101, 102, 103).

The goal of the competition policy (like of the trade policy) is to eliminate activities infringing on free competition or free trade through unlawful practices and agreements. ${ }^{27}$ It is worth mentioning that "the state aid used for achieving allocation goals, thus substituting economic mechanisms of specialisation, particularly if designed to fix the existing inefficient structures of production, employment and exports, is particularly harmful” (Gawlikowska-Hueckel and Zielińska-Głębocka, 2004, p. 136).

Art. 101 of TFEU says that there are exceptions to these rigorous provisions. They may not be applied to enterprises which contribute to "improving the production or distribution of goods or to promoting technical or economic progress".

The EU laws concerning trade and competition policies clearly define aid rules (Korbutowicz, 2016). The EU policies, however, create a logical matrix which practically means that within trade and competition regulations there are exceptions which can switch on tools of support, within the policies of cohesion, agriculture, industry and innovation.

The most important of them (in terms of the volume of expenditure) is the cohesion (regional) policy, which has also undergone a significant evolution as far as goals, scope, and priorities of actions are concerned.

The growth of its importance is usually associated with the establishment (1973) and the operability (1975) of the European Regional Development Fund (the first tool for financing regional policy was created 1958, i.e. the Social Fund, which focused its intervention on the labour market; in 1964 the Guarantee Section of the European Agricultural Guidance and Guarantee Fund (EAGGF) was created. The Section

27 The following shall be prohibited as incompatible with the internal market: all agreements between undertakings, decisions by associations of undertakings and concerted practices which may affect trade between Member States and which have as their object or effect the prevention, restriction or distortion of competition within the internal market (TFUE, 2004). 
financed projects related to the restructuring of rural areas). ${ }^{28}$ The 45 -year-long experience with the ERDF resulted in numerous publications on the theory of cohesion, convergence, and catch up process, and to a genuine evaluation of the effectiveness of the policy (which should result in a better standard of living in the regions of the lower level of social and economic development).

Of the monographs focusing on the efficiency of the policy, we ought to mention the studies of Bachtler and Mendez (2007). The macroeconomic results of the policy have been presented by Bradley (2009), Bradley and Zaleski (2003), and Bradley, Morgenroth, and Untiedt (2003). At EU level, cyclic reports are produced on the development of socio-economic cohesion (the most recent was published in 2017). This type of research was conducted in Poland by Szlachta (1992, 2010), Zaucha et al. (2015), Churski (2008), Gorzelak (2014), Łaźniewska, Gorynia, and Chmielewski (2012). Numerous studies criticise the efficiency of regional policy. These include Sapir's report (Sapir, 2003) and papers of Ederveen, Gorter, Mooij, and Nahuis (2002) and Boldrin and Canova (2001). These publications underline the waste of resources, lack of efficient control, corruption, the increase in debt due to the necessity of cofinancing European projects.

The goal of cohesion policy (regional, structural) is defined by the provision of the Treaty: Member States are "ANXIOUS to strengthen the unity of their economies and to ensure their harmonious development by reducing the differences existing between the various regions and the backwardness of the less-favoured regions.” The legal foundations of the regional policy were formulated in the Single European Act.

Radical changes in cohesion policy started with the reforms adopted within the so-called Delors Package (Gerbet, 2016). Legal foundations of the reformed policy were formed under the Treaty on European Union (TEU) where Art. 130A contains the following provision: "In order to promote its overall harmonious development, the Community shall develop and pursue its actions leading to the strengthening of its economic and social cohesion. In particular, the Community shall aim at reducing disparities between the various regions and the backwardness of the least-favoured regions”.

The new solutions consisted in increasing inputs for the regional development, integrated programming, multi-year financing, focusing recourses on precisely defined goals, defining the rules and the directions of operations at the Community level, and comprehensive monitoring.

28 Under the Treaty of Maastricht (1992), the Cohesion Fund was established which was and is earmarked for the countries where the Gross National Income was lower than 90\% then EU average. The Fund supported the development of particularly capital-intensive structural investments. In 1967, within the structures of the European Commission, Directorate Regional for Regional Policy (earlier called DG XVI, afterwards DG REGIO) was established. 
Further changes in legal foundations concerning the cohesion policy were introduced under the Treaty of Lisbon, wherein Art. 3 and Arts. 174-178 previous provisions were expanded.

The evolution of cohesion policy was connected with two processes: the broadening of the integration, which resulted in the formulation of new goals of regional policy, or significant extension of the area of intervention ${ }^{29}$ and the deepening of integration, which resulted in higher exposure to competition (which affected most of all poorer regions).

Therefore, the instruments of regional policy were supposed, first of all, to neutralise the adverse effects of the deepening integration on the regions which due to their low standard of living - were particularly severely hit by the growing competition.

Cohesion policy includes the six-year programming and financing framework, which guarantees the reception of funds in the long run. At present, the sources of funding include the European Regional Development Fund, the European Social Fund and, although not a structural fund, the Cohesion Fund supporting the two. Legal foundations for more activity of the European Investment Bank have been established; the Bank is deeply involved in money lending activities, thus supporting the financing of European projects.

The new approach to cohesion policy in the period of 2014-2020 was related to the changes in the paradigm of that policy; these amendments were related to the studies carried out by international organisations, first of all by The World Bank (2010) and the OECD (2009).

The attention of the World Bank was focused on the importance of metropolitan areas, which - because of high innovation potential, human capital included - guarantee that funds are invested more effectively.

The $7^{\text {th }}$ Report on economic, social, and territorial cohesion (Dijkstra, 2017) says that the Regional Competitiveness Index (RCI) is the highest in strong capitals and other metropolitan regions. It results from the fact that the existing environment favours new ideas, products, and processes, thanks to which there is an inflow of creative and qualified employees. The activity increases the tendency to undertake the business activity and results in creating clusters. Thus, it makes the areas more innovative, the enterprises stronger, more ready to take the risk, and more open to internalisation.

29 As an example of the problems of different nature the regional policy had to face together with expanding the Union by well-off countries (Sweden, Finland, Austria) in 1995 were occurring in some northern reaches of Finland and Sweden depopulation tendencies (due to adverse climatic conditions). The highest challenge was the $2004 \mathrm{EU}$ enlargement, when the population of the EU increased by $20 \%$ due to the accession of 10 countries, while the GDP increased by $5 \%$ GawlikowskaHueckel (2005); Pietrzyk (2004). 
On the other hand, the OECD studies (2009) stress the role of endogenous resources and qualitatively new ideas, such as information society, knowledge-based economy, communication and information technologies, learning regions. The rationality of allocating resources to well-developed regions results from the fact that their potential facilitates the creation of innovative solutions, the beneficiaries of which (sooner or later) will become the less developed ones. It is supported by the diffusion of knowledge and development processes. The approach of this type undermines the sense of carrying out the compensatory regional policy.

The results of the research of international institutions and the debate at EU level was reflected in the decisions concerning the cohesion policy in the programming period of 2014-2020. At the same time, the improvement of the competitiveness level was stressed, simultaneously limiting the pool of resources earmarked for cohesion. Scientific research and innovations, implementation of digital agenda, support for SMEs and low-carbon economy were regarded as priorities (Gawlikowska-Hueckel and Szlachta, 2014).

These priorities are consistent with the Europe 2020 strategy (European Commission, 2010c), which assumes that development should be smart (based on knowledge and innovation), sustainable (using the resources in an efficient way), and more competitive.

The strategy emphasises the impact of exports on growth: "The EU prospects thanks to trade - it exports all over the world and imports both raw materials and finished products. Under high competitive pressure on the export markets (...) we must become more competitive in relation to our major trade partners by increasing our efficiency".

This also refers to the advancement of the regions and particularly to those whose productivity is lower than the EU regional average.

The special role of the cohesion policy is demonstrated by the fact that in 20142020 the largest pool of funds, EUR 351.8 billion was allocated to it, which makes it the main investment tool. It should, however, be noted that the share of the less developed regions and of the Cohesion Fund in the allocation went down from ca. $80 \%$ to 70\% (Szlachta, 2012).

Another policy which makes it possible to use exporter support instruments at the regional level is the industrial policy, within which 'the new approach' was devised. In the initial period of the changes, it was decided that it should provide a more unequivocal response to globalisation-related problems. The challenges are important enough for sectoral instruments (previously discarded by the policy) to be engaged. The European Commission stresses the need for the introduction of key enabling technologies, flagship initiatives and priority lines.

In addition to "the challenges of globalisation and adjusting production processes and products to a low-carbon economy" (European Commission, 2010b), reindustrialisation of EU member states has become an issue. "Europe needs to reverse the declining role of industry in Europe for the 21st century. ... To achieve this, a 
comprehensive vision is needed, focusing on investment and on innovation, but also mobilising all the levers available at EU level, notably the single market, trade policy, SME policy, competition policy, environmental and research policy in favour of European companies’ competitiveness” (European Commission, 2012).

Two flagship initiatives concerning industry have been formulated in the Europe 2020 paper:

- An industrial policy for the globalisation era, which is supposed to engage tools that will improve the business environment for SMEs and "to support the development of a strong, sustainable industrial base able to compete globally";

- "Innovation Union”, which is to improve access to finance for research and innovation so as to ensure that innovative ideas can be turned into products and services which create growth and jobs.

The new approach to industrial policy in the EU (European Commission, 2012) is based on the assumption that competitiveness and sustainable EU industrial development are a priority. If this goal is to be achieved, the industrial policy must be understood more broadly and cover the areas directly related to costs, prices and innovationbased competitiveness of the industry and its individual sectors, but also to account for the impact of all other political initiatives on competitiveness.

Industry plays a key role, in view of the fact that one in four new jobs is in industry and results in one job in the service sector. Some $75 \%$ of the export volume is from industry, which is also responsible for $80 \%$ of private R\&D expenditure. ${ }^{30}$

From the perspective of export support instruments, it is important that industrial policy accepts the use of selective tools (the choice of industries and priorities). Vertical measures (taken within the industrial policy) can be coupled with support for the industries decided to be of key importance for smart specialisations.

The approach of various policies and the set of tools they have at their disposal, together with limitations resulting from the EU legal provisions point to the relatively narrow margin of the authorities' freedom as far as the internationalisation support at the regional level is concerned. As has already been mentioned, this results mainly from rigorous provisions of the policy of competition, which hinder a broader use of aid.

The 7th Report on Economic, Social, and Territorial Cohesion (Dijkstra, 2017, p. 189) says that the fundamental source of support for the SMEs was the aid granted "to mitigate the effects of the crisis through loans (when no other sources of funding are available)". Direct support (in 2007-2013) was granted to 2\% SMEs in the EU (400,000 out of 23 million).

30 A change in industrial policy and industry revival attempts are also linked with the loss of 3 million industrial jobs in EU member states in the wake of the 2008 crisis European Commission (2012). 
The analysis discussing the kind of applied tools is the answer to the third question asked in the introductory part of the chapter.

The survey of the possibility of supporting the expansion to foreign markets opens the presentation of the institutions created in support of exporters in Poland.

Table 11.1 shows that Polish institutions of export support offer mainly activities of horizontal nature, which are in conformity with trade and competition policies. These activities must not be disregarded. As the research of the International Trade Centre shows, the role of the organisations promoting trade is very important, and their activities stimulate growth (International Trade Centre, 2016).

Some of the activities of the institutions mentioned above are financially supported. For example, costs of participation in fairs and exhibitions abroad, participation in outgoing trade missions, costs of international certification, implementation of sectoral promotional projects or the organisation of conferences and shows are subsidised.

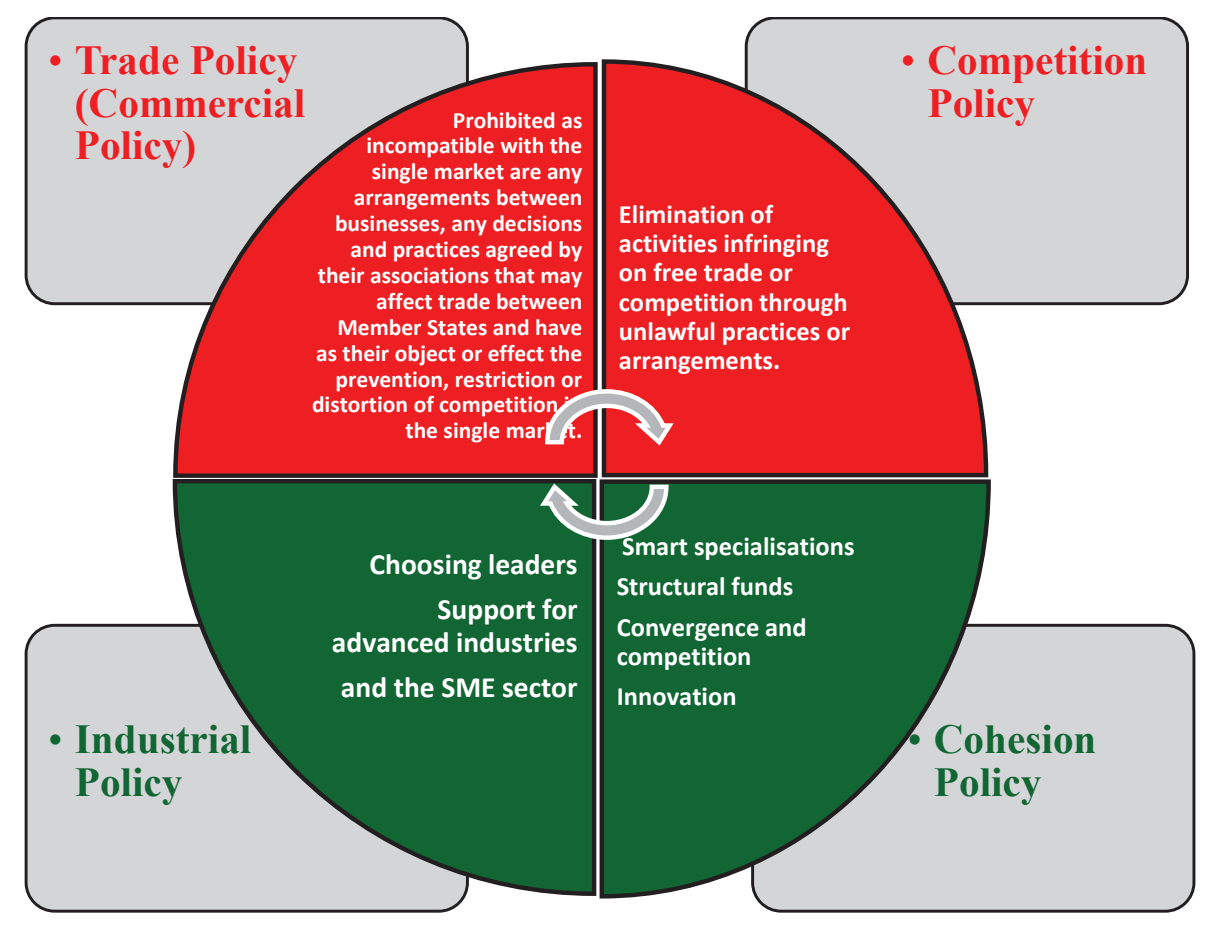

Figure 11.1: Limitations and opportunities of internationalisation support under EU policies Source: own elaboration. 
Regional chambers of commerce are interested in creating "groups of interest" composed of a couple or a dozen of companies interested in a common project (such as standardisation of services or financing a common laboratory).

It should be mentioned that membership in chambers of commerce in Poland is not mandatory (like in the UK, unlike in Germany, where the system requires membership of all businesses, which translates into greater advantages of being a member). The limited participation of businesses is a curb on the effectiveness of the Agency.

Export financing is based on an OECD document Arrangement on Officially Supported Export Credits, which was incorporated into the acquis in April 1978.

In Poland, the allowed instruments include government loans (including tied aid), export credits granted by the Bank Gospodarstwa Krajowego (BGK), refunds of part of the interest on fixed-rate export credits granted by the BGK and the premiums on credit insurance by KUKE SA.

Internationalisation support instruments within the cohesion policy are reflected in regional operational programmes (RPOs) - see tables 11.2 and 11.3. As seen in the RPOs of most voivodships, problems of internationalisation of businesses are included. This shows that regional authorities are aware of export-related growth opportunities.

It should be added that regional operational programmes are financed under the cohesion policy, so the support funding comes from the EU budget.

Noteworthy is the fact that support opportunities for the voivodships of eastern Poland were created within Activity 1.2 SME Internationalisation by a dedicated programme Polska Wschodnia (Eastern Poland) and national operational programmes. Nevertheless, two of the voivodeships concerned, Warmińsko-mazurskie and Lubelskie, included internationalisation efforts in their regional programmes. The RPO of the former includes Measure 3b: Preparation and Implementation of New Business Models for SMEs with a View of Their Internationalisation, while the programme of Lubelskie includes Measure 3.6. Business Marketing.

It is interesting that relatively the greatest support is offered by the voivodeships considered to be internationalisation leaders: Mazowieckie, Wielkopolskie, Dolnośląskie and Małopolskie.

It is interesting to identify support tools used in the Spanish regions and compare them with those used in Poland.

Summarizing, the EU's common commercial policy and especially competition policy are a curb on the use of many direct tools to support exporters at the regional level. Taking into account these restrictions, regions of Poland and Spain use instruments that are horizontal in nature or are allowed by the EU regulations, regarding, e.g. the SME sector (as not threatening competition). That is why the tools used in both countries are similar.

The support of the SME sector is most often used; this support takes various forms such as: creating new SMEs business models to increase international expansion, improving the competitiveness of the business sector, development of SMEs' 
Table 11.1: Various types of institutions and kinds of support for exports at the regional level

\begin{tabular}{|c|c|c|}
\hline $\begin{array}{l}\text { Institutions of support at the } \\
\text { national level }\end{array}$ & $\begin{array}{l}\text { Institutions of support at the } \\
\text { regional level }\end{array}$ & Kinds of support offered \\
\hline $\begin{array}{l}\text { Polish Investment and Trade } \\
\text { Agency } \\
\text { Polish Agency for Enterprise } \\
\text { Development }\end{array}$ & $\begin{array}{l}\text { Regional chambers of com- } \\
\text { merce } \\
\text { Agencies of regional develop- } \\
\text { ment } \\
\text { Special economic zones } \\
\text { Regional clusters (brand } \\
\text { promotion) } \\
\text { Regional exporters' associa- } \\
\text { tions }\end{array}$ & $\begin{array}{l}\text { Promotion } \\
\text { Organisation of fairs and } \\
\text { exhibitions } \\
\text { Networking activities } \\
\text { Information on markets } \\
\text { Organisation of economic } \\
\text { missions } \\
\text { Aid in obtaining product } \\
\text { certificates } \\
\text { Internet export promotion } \\
\text { websites }\end{array}$ \\
\hline Foreign Trade Offices & & $\begin{array}{l}\text { Market information (analyses, } \\
\text { reports, guidelines), } \\
\text { Co-networking with local com- } \\
\text { panies and institutions, } \\
\text { Organisation of trainings for } \\
\text { Polish and foreign companies, } \\
\text { Status reports on business } \\
\text { partners }\end{array}$ \\
\hline
\end{tabular}

Source: own elaboration.

innovation potential and their entrepreneurship to allow them to access new markets in the globalized economy, promotion of an entrepreneurial culture, facilitation for exporters to improve export diversification, and increase of the number of sales markets. Four Polish and ten Spanish regions declare such form.

Assistance in participating in fairs and exhibitions is included in operational programmes of eight Polish regions and four Spanish regions. Other forms of support include programmes promoting exports and internationalisation, guidance for companies embarking on the process of internationalisation, advisory services in the field of the undertaking and developing export activities in strategies, export development plans, and legal advice.

Promoting partnerships, collaborations, creating cooperation networks, and joint projects are also very important.

It should also be emphasized that certain tools are related to the specificity of the region, e.g. in the Baleares Programme, it is mentioned that the traditional "sea, sun and sand" business model has to be transformed at regional and firm levels. Diversification is necessary to escape low-cost competition. 
The Canary Islands also want to "support companies with export potential in the field of renewable energy and water treatment, activities related to the maritime sector". It should be added that only in one Polish region (Zachodniopomorskie) is the support earmarked only for enterprises operating in the area of smart specialisations of West Pomerania. 


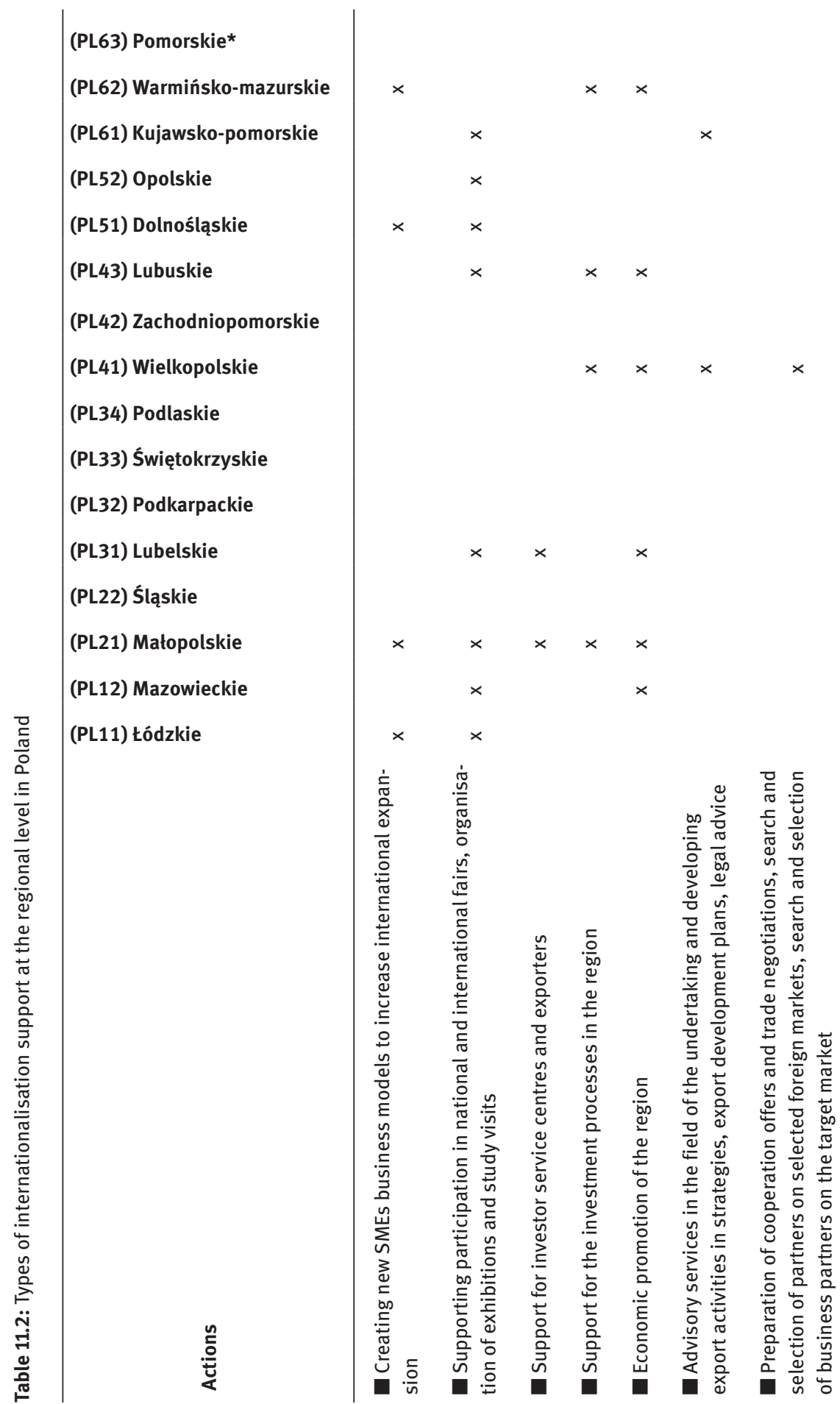




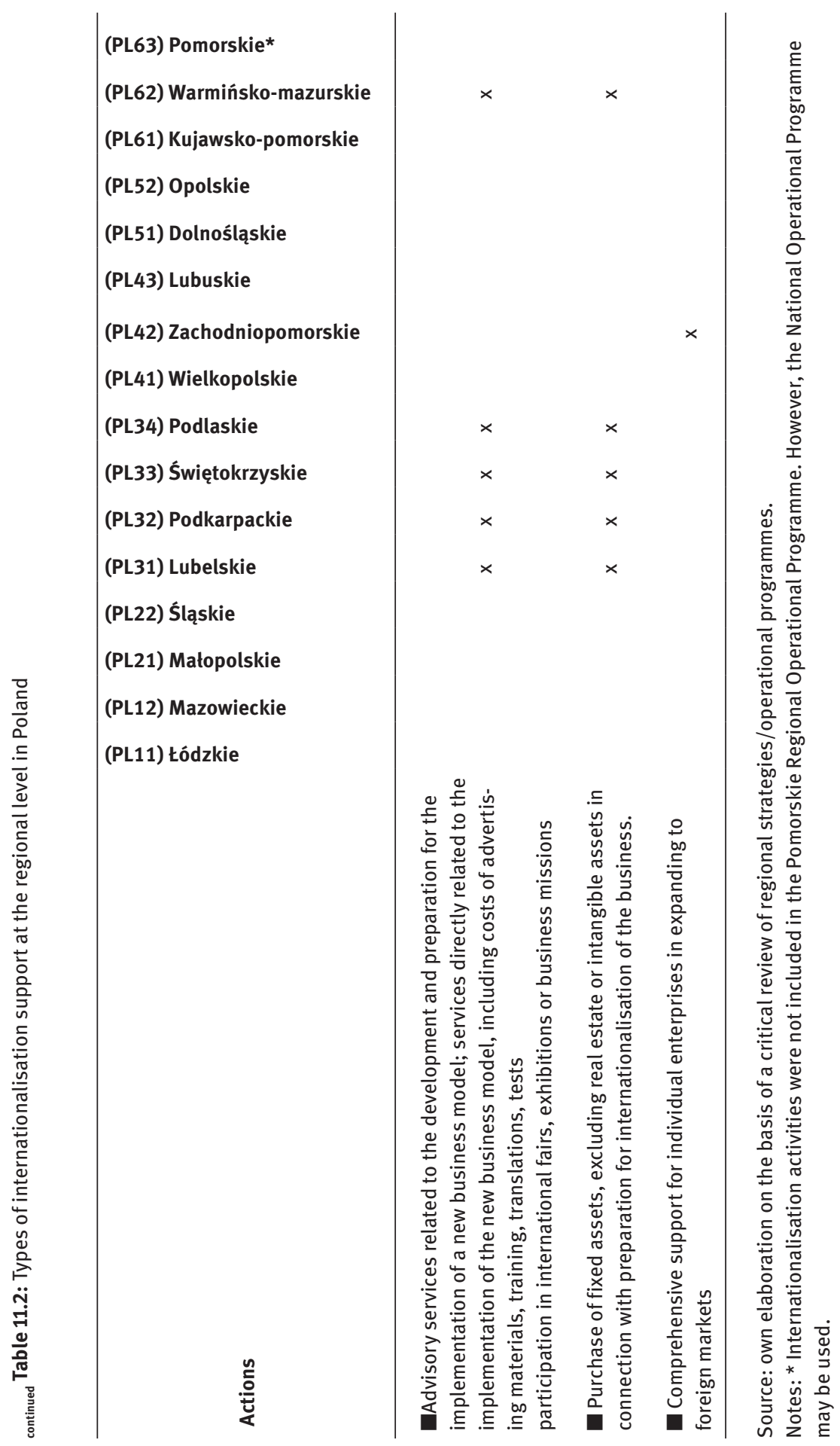




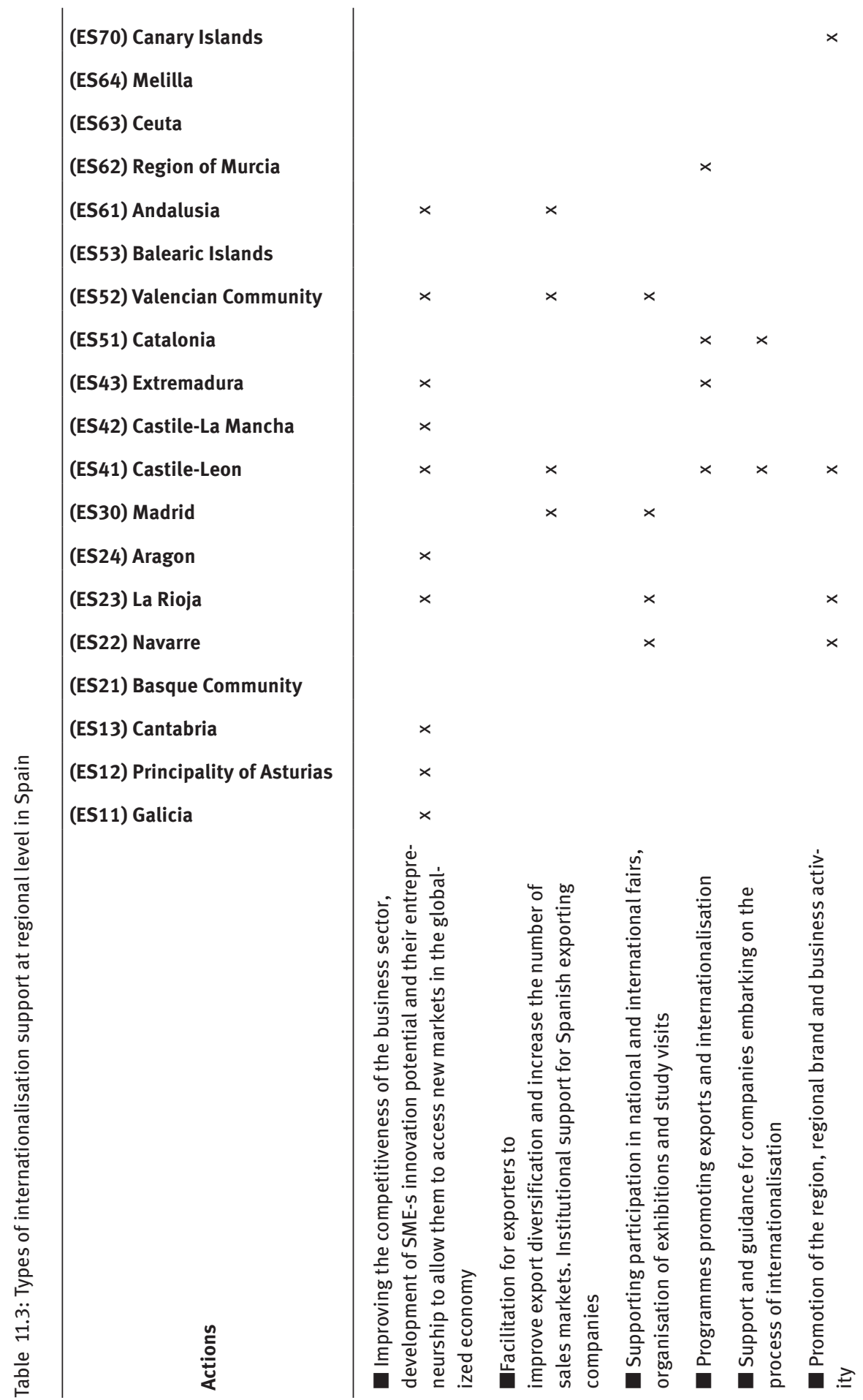




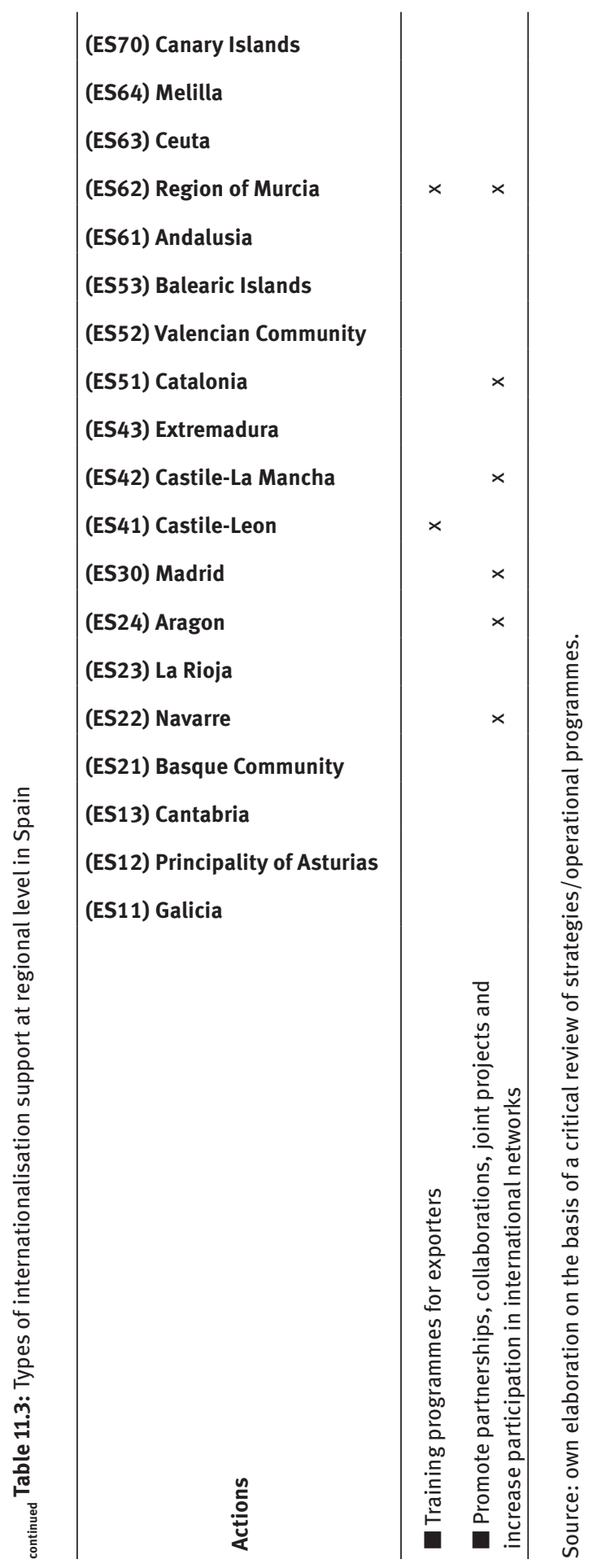

